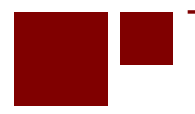

C E N T E R for RETIREMENT RESEARCH at BOSTON COLLEGE

\title{
WILL MORE WORKERS HAVE NONTRADITIONAL JOBS AS GLOBALIZATION AND AUTOMATION SPREAD?
}

\author{
Matthew S. Rutledge, Gal Wettstein, and Sara Ellen King
}

CRR WP 2019-10

July 2019
Center for Retirement Research at Boston College
Hovey House
140 Commonwealth Avenue
Chestnut Hill, MA 02467

Tel: 617-552-1762 Fax: 617-552-0191

https://crr.bc.edu

Matthew S. Rutledge is an associate professor of the practice of economics at Boston College and a research fellow of the Center for Retirement Research at Boston College (CRR). Gal Wettstein is a research economist at the CRR. Sara Ellen King is a research associate at the CRR. The research reported herein was pursuant to a grant from the Alfred P. Sloan Foundation. The findings and conclusions expressed are solely those of the authors and do not represent the views of the Alfred P. Sloan Foundation or Boston College.

(C) 2019, Matthew S. Rutledge, Gal Wettstein, and Sara Ellen King. All rights reserved. Short sections of text, not to exceed two paragraphs, may be quoted without explicit permission provided that full credit, including $(\mathcal{C}$ notice, is given to the source. 


\begin{abstract}
About the Center for Retirement Research
The Center for Retirement Research at Boston College, part of a consortium that includes parallel centers at the National Bureau of Economic Research, the University of Michigan, and the University of Wisconsin-Madison, was established in 1998 through a grant from the U.S. Social Security Administration. The Center's mission is to produce first-class research and forge a strong link between the academic community and decision-makers in the public and private sectors around an issue of critical importance to the nation's future. To achieve this mission, the Center conducts a wide variety of research projects, transmits new findings to a broad audience, trains new scholars, and broadens access to valuable data sources.
\end{abstract}

Center for Retirement Research at Boston College

Hovey House

140 Commonwealth Avenue

Chestnut Hill, MA 02467

Tel: 617-552-1762 Fax: 617-552-0191

https://crr.bc.edu

Affiliated Institutions:

The Brookings Institution

Mathematica - Center for Studying Disability Policy

Syracuse University

Urban Institute 


\begin{abstract}
Recent research has called attention to alternative employment arrangements that often leave workers without retirement and health benefits and with income instability. At the same time, workers are facing increasing competition from automation and globalization. This competition is of special concern for older workers, who increasingly need longer careers to secure an adequate retirement and jobs with benefits to enable saving and access to affordable health care. The question is: are these "nontraditional" jobs more prevalent in areas more exposed to such competitive pressures and are older workers more likely to hold them? The study uses the 1996-2008 panels of the Survey of Income and Program Participation (SIPP) to track the share of workers in nontraditional work arrangements - defined based on characteristics of the job including retirement plan coverage, health insurance coverage, and hour or wage instability. It then estimates whether workers are more likely to be in nontraditional arrangements, or transition from traditional to nontraditional work, in areas with greater exposure to trade and automation. The findings suggest that globalization does not have a major effect, but automation does; a 1-standard deviation increase in the use of industrial robots is associated with an 11-percent increase in nontraditional employment. This relationship is even stronger for older workers: a 1-standard-deviation increase in automation is associated with a 17-percent increase in nontraditional work at ages 50-62. As automation continues to increase, jobs that offer retirement savings, health insurance, and stable income may continue to decline, and the impact is likely to be particularly felt by older workers who may need these benefits the most.
\end{abstract}




\section{Introduction}

A burgeoning literature has focused on workers engaging in what are often referred to as “alternative work arrangements," such as independent contracting, on-call work, or temporary work (Katz and Krueger 2016, 2019; Jackson, Looney, and Ramnath 2017; Abraham et al. 2018; Farrell and Greig 2017; Robles and McGee 2016; and Collins et al. 2019). While the workers included in this category vary greatly across studies, their common denominator is best expressed in what they lack: retirement and health benefits that denote a high-quality job, and some measure of stability in their incomes, hours, and employment status. Such jobs seem especially common among older workers (Katz and Kruger 2019), which is particularly concerning as they increasingly require jobs that will allow them to save for looming retirements and cover increasing health expenditures.

The focus of this study is whether the share of jobs lacking the markers of "traditional" employment is greater in places where the labor market has been weaker - in particular, because of the external pressures of globalized competition (especially from China) and the automation of routine tasks - and whether the effect is any more or less extreme for older workers specifically. Using the Survey of Income and Program Participation (SIPP), this paper defines nontraditional work in two different ways: 1) broadly as the absence of both retirement and health benefits; and 2) more restrictively as the absence of these benefits plus some volatility in hours, earnings, or employment.

The analysis focuses on whether nontraditional work is concentrated in areas affected by globalization and automation. It also examines the extent to which individuals first observed in traditional jobs move toward nontraditional work at greater rates when local labor markets face these external pressures. The results will help policymakers better understand how future increases in globalization and automation could affect the spread of nontraditional work going forward, both to workers in general and to late-career workers in particular.

The results suggest that nontraditional work is more likely in states with greater exposure to automation, but exposure to import competition has no significant relationship with nontraditional work. A 1-standard-deviation increase in automation increases the probability that an individual is in a nontraditional job by about 11 percent for all workers and 17 percent for workers ages 50-62. Furthermore, the results provide suggestive evidence that traditionally 
employed workers tend to move to nontraditional jobs when their industry is exposed to increased automation, but such movement may still be too rare to find a conclusive relationship.

The rest of the paper proceeds as follows. The next section reviews the literature on the markers of nontraditional work arrangements. The third section describes how the analysis uses SIPP data to define nontraditional work, and the fourth outlines the econometric approach to estimating the relationship between nontraditional work and globalization and automation. The fifth section presents results, and the final section concludes that, given the positive correlation between nontraditional work and industrial robot utilization, the likely spread of automation to other industries could push more workers into nontraditional work.

\section{Background and Previous Literature}

While research on nontraditional work dates back decades (see an early review from Barker and Christensen 1998), it has gained renewed prominence in the media and among social scientists, especially after Katz and Krueger's 2016 study found an increase in so-called "alternative" arrangements from 10 percent to 15 percent of the workforce over the 2005-2015 period. Later evidence from those same authors suggested a slightly more muted upward trend in primary employment in alternative arrangements, and suggested alternative jobs are often secondary jobs (Katz and Krueger 2019). Indeed, Collins et al. (2019) find evidence that, although a higher share of workers are filing IRS Form-1099s indicating independent contracting work, almost all of the growth is from people using that work as a secondary source of income. ${ }^{1}$

Collins et al. (2019) also focused on another popular topic in this literature: the rise of the gig-economy facilitated by the use of online platforms. Their finding is common to the literature - these types of jobs have increased recently but are still rare, especially as primary jobs. For example, Farrell and Greig (2016), examining bank records for J.P. Morgan Chase accountholders, find increased incidence of deposits from "gig-economy" payers, though the share of workers with this direct evidence of gig-economy employment remained below 2 percent as of 2016. In contrast to studies looking at gig workers, other studies include broader definitions of nontraditional work, encompassing direct-selling to consumers, part-time work, and small

\footnotetext{
${ }^{1}$ Jackson, Looney, and Ramnath (2017) similarly use administrative tax records, but instead identify workers with self-employment income and only small amounts of business expenses, which may indicate independent contracting. They find that the share of the workforce with this tax filing status nearly doubled from 1999 to 2014, though it remains only around 4 percent of workers.
} 
business ownership. Under this more expansive definition, the share of workers in nontraditional arrangements is as high as 30 percent (Robles and McGee 2016) or even 40 percent (GAO 2015) of workers. In other words, under the various definitions used in this literature, the range of estimates of these alternative jobs can fall anywhere between 2 and 40 percent.

Because of the lack of consensus over the definition of nontraditional work, the current study focuses on the characteristics of jobs - ultimately, what matters for economic security is not the label given the job, but factors such as fringe benefits and the volatility of wages, hours, and employment. This focus on job characteristics instead of the nature of the employer relationship is also related to the strand of the literature examining the quality of jobs. For example, Kalleberg, Reskin, and Hudson (2000) report that, as of 1995, 31 percent of American workers were in jobs that fit the CPS definition of alternative arrangements, and/or lacked retirement and health benefits, and/or carried low or volatile pay. In a review, Osterman (2013) finds that jobs with unpredictable wages are becoming more common and fringe benefit offers are declining.

In any case, the preceding studies mostly focus on counting the workers in various kinds of jobs, rather than how these kinds of arrangements may have arisen. These studies therefore lack an exploration of whether nontraditional employment appears to be related to macroeconomic pressures and secular trends in the labor market toward increased globalization and automation - and in particular, whether they impact older workers' ability to secure an adequate retirement. Autor, Dorn, and Hanson (2013) find greater expenditures on retirement and disability benefits in local labor markets that are more subject to import competition from China, which suggests that older workers are driven into earlier retirement when globalization reduces their job prospects. The same authors find that workers in manufacturing industries that were most exposed to import competition experienced more churn, particularly when they had low earnings to begin with (Autor, Dorn, Hanson, and Song 2014). ${ }^{2}$ Similarly, Acemoglu and Restrepo (2017) find that local labor markets exposed to automation see employment and wage

\footnotetext{
${ }^{2}$ This literature is large and growing. For example, see also Balsvik, Jensen, and Salvanes (2015); Acemoglu, Autor, Dorn, Hanson, and Price (2016); Bloom, Draca, and Van Reenen (2016); and Pierce and Schott (2016).
} 
losses, though they do not report results by age. Overall, previous research has not examined whether these trends push workers into nontraditional jobs. ${ }^{3}$

\section{Data}

The project uses the Survey of Income and Program Participation to examine the share of individuals in nontraditional or traditional jobs over the 1998-2012 period. The SIPP is a longitudinal household survey conducted by the U.S. Census Bureau, sampling individuals within each household once every four months (a "wave") over a period of $2 \frac{1}{2}$ to 4 years. This study uses panels of individuals that were sampled beginning in 1996, 2001, 2004, and 2008.

The analysis uses SIPP data on labor market outcomes, demographics, family structure, and health insurance coverage from the core questionnaire, which is fielded at each interview. The project also uses information from SIPP topical modules that are fielded periodically in specific waves. The topical modules of interest are the ones covering: 1) retirement plan offers and participation; and 2) information from IRS tax forms. The following two subsections detail how the core and topical modules are used to define nontraditional work and then to identify transitions from traditional into nontraditional status. The final subsection focuses on measurements of globalization and automation.

\section{Defining Nontraditional Work}

The analysis uses two definitions of nontraditional work. The first is less restrictive, focusing exclusively on whether a job lacks employer-sponsored retirement and health benefits. However, many studies of nontraditional jobs are also concerned with instability. Furthermore, workers who are the secondary earners in their households may prefer a job with greater earnings but less generous fringe benefits. So the study also uses a second, more-restrictive definition which requires jobs to both lack those benefits and to have volatility in employment status, earnings, or work hours.

While the full SIPP panel includes information on both retirement and health benefits, the timing of the availability of this information creates some limitations. The data on retirement

\footnotetext{
${ }^{3}$ Ongoing Sloan-funded work by Richard Freeman and colleagues examines the extent to which automation affects employer demand for older workers, but does not focus specifically on whether those firms create nontraditional arrangements for those workers. Other papers in this vein include Hemous and Olsen (2014); Acemoglu and Restrepo (2018); Autor and Salomons (2018); and Graetz and Michaels (2018).
} 
plan offers is exclusively available in a topical module that is usually fielded only once per SIPP panel. Employer-sponsored health insurance offers, however, are asked in a different topical module. ${ }^{4}$ Because nontraditional work is, either implicitly or explicitly, more volatile, limiting the sample to jobs that last through both topical modules would be too restrictive.

Instead, the study takes advantage of the health insurance data available in the SIPP core, which documents participation in an employer-sponsored health plan rather than a health insurance offer. The first concern with using participation instead of offers is that some workers marked as in nontraditional jobs might in fact be offered a health plan but turn it down if the plan carries a high premium or is of low generosity. But it is arguably sound to consider jobs offering no plan and jobs that offer plans that are too unattractive to take up as being essentially equal. The second concern is that some workers who do not participate in a health plan may opt for health insurance through their spouse, even if they have coverage available through their own employer. Supplemental analysis of the CPS Contingent Worker Supplement indicates that the majority of married workers participating in their spouse's employer plan are offered health insurance by their own employer as well. ${ }^{5}$ Therefore, the analysis would label a worker's job as nontraditional only if the worker did not have health insurance through their own or a spouse's job. This restriction therefore yields a conservative estimate of the size of the group of nontraditional jobs, suggesting that any positive association with the probability a worker is in nontraditional work would be a lower bound on the true correlation. ${ }^{6}$

\footnotetext{
${ }^{4}$ In the 1996, 2001, and 2004 panels, the topical module with health benefit offers is in wave 5, two waves - or about 8 months - before the detailed information on pension offers. In the 2008 panel, the questions on health benefit offers are asked 20 months prior to the pension wave.

${ }^{5}$ In the CPS, roughly 70 percent of married individuals with health insurance through their spouse were also offered it at their job.

${ }^{6}$ The estimate may be a lower bound on the magnitude of effects for two reasons. First, classical measurement error in the dependent variable can lead to attenuation bias in a discrete-response model; see Hausman, Abrevaya, and Scott-Morton (1998). Second, if undercounting non-traditional work is more likely in areas with high exposure to automation and trade, then this non-classical measurement error would also lead to understatement of the correlation between non-traditional work and these factors. Such a situation might arise, for example, if areas with high levels of automation lead to a shortage of jobs providing employer-sponsored insurance (ESI), which in turn leads households to specialize, with one spouse seeking ESI with family coverage. In these areas, in particular, some nontraditional jobs would be excluded from the analysis because they would be associated with workers whose spouses have ESI, and thus cannot be definitively assigned to nontraditional work.
} 


\section{Transitions between Jobs}

The analysis is also interested in whether globalization and automation push workers from traditional into nontraditional jobs. The limitation in exploring these transitions is that the SIPP topical module on retirement plan offers is fielded only once per panel, making tracking workers' nontraditional job status over time difficult. However, the SIPP does contain a separate topical module on tax returns asked exactly one year before the detailed retirement plan module. While the tax module does not include enough information to identify nontraditional jobs, it does allow for definitively identifying traditional jobs: if a worker is making tax-deferred contributions to a $401(\mathrm{k})$ or has employer-sponsored health insurance coverage, the job must have offered those benefits. The paper follows these workers in traditional jobs one year later to see if they have moved to a nontraditional job in the wave in which the full retirement plan topical module is available. As with the analysis of nontraditional work status, this approach would estimate a lower bound on any positive relationships with transitions into nontraditional work, as the analysis may miss some workers transitioning into nontraditional jobs.

\section{Quantifying Exposure to Globalization and Automation}

The final piece of information is the workers' exposure to globalization and automation. The globalization measure is based on data on Chinese imports to the United States from Autor, Dorn, and Hanson (2013). ${ }^{7}$ These data are at the Commuting Zone (CZ) level, and available in 1990, 2000, and 2007. They are aggregated to the state level, weighted by the share of the national population of CZs in $1990 .^{8}$ The data are interpolated linearly between 1990 and 2000, and held constant after 2007; while more updated data would be ideal, keeping the values constant after 2007 ensures that the variation in trade is driven by the plausibly exogenous entrance of China into world trade, and not by its more moderate and possibly demand-driven growth since.

The analysis measures exposure to automation in the same way as Acemoglu and Restrepo (2017), based on the number of industrial robots per 1,000 workers, calculated for 19

\footnotetext{
${ }^{7}$ The original data were acquired by Autor, Dorn, and Hanson (2013) from the U.N. Comtrade database. These data are available online at http://www.ddorn.net/data.htm.

${ }^{8}$ These data exclude Alaska and Hawaii; however, Washington, DC is counted as a state. Furthermore, Maine and Vermont are aggregated into one single state for the purpose of the analysis, to match SIPP definitions that are consistent across panels; similarly Wyoming, North Dakota, and South Dakota are considered a single state.
} 
different industries. The data to construct this measure were collected by Acemoglu and Restrepo from the International Federation of Robots (for number of industrial robots) and from the U.S. Census and the American Community Survey (for number of workers by industry). This paper takes the robots per 1,000 workers numbers by industry directly from Table A1 in Acemoglu and Restrepo (2017).

The robots per 1,000 workers ratio is observed for the years 2004, 2007, and 2014, and is assumed to be 0 in 1980. The analysis uses these industry-level measures to calculate state-year level robot penetration as follows: first, three-digit industry codes from the CPS are classified into the 19 industry categories enumerated in Acemoglu and Restrepo (2017). ${ }^{9}$ Second, the shares of employment of these 19 categories in each state are calculated from the 1990 CPS (prior to the analysis period). Third, state-year robot penetration is calculated in 2004, 2007, and 2014 based on the industry-level robots to workers ratio weighted by the 1990 state industry shares. Finally, the measure is interpolated linearly between 1980, 2004, 2007, and 2014 to arrive at relevant values for the SIPP survey years of 1997-1998, 2002-2003, 2005-2006, and 2011-2012.

Finally, for both the measure of globalization and the measure of automation, the variables are standardized to their Z-scores, so that in the analysis every unit change in either measure corresponds to a 1-standard-deviation change.

\section{Methodology}

The project first examines the extent to which nontraditional jobs, as defined by this project, have become more common over time, and presents descriptive statistics on the characteristics of workers in nontraditional versus traditional jobs, as well as workers who transitioned from traditional to nontraditional status. The focus of the empirical analysis is whether more workers are in nontraditional jobs and whether more workers in traditional jobs move to nontraditional work in labor markets with greater exposure to globalization and automation. To answer these questions, the main analysis estimates several regression models.

The first model - the static analysis - estimates the relationship between nontraditional work and exposure to globalization and automation in an individual's state of residence $(s)$, among those who are working at year $t$ (the wave of the SIPP pension topical module) using a

\footnotetext{
${ }^{9}$ A crosswalk is available from the authors of the current paper upon request.
} 
probit regression. The dependent variable is an indicator equal to 1 if worker $i$ is categorized as being in a nontraditional job: ${ }^{10}$

$$
\operatorname{NonTrad}_{i s t}=\Phi\left(\alpha_{1} \text { Trade }_{s t}+\alpha_{2} \text { Auto }_{s t}+\gamma X_{i s t}+\zeta_{s}+\tau_{t}+\varepsilon_{i s t}\right)
$$

The key independent variables are the first two: Trade $_{s t}$ is an index of the degree to which industries in the worker's state have faced exposure to trade from China by year $t$; and Auto $_{s t}$ is an index measuring the degree to which industries in state $s$ have faced exposure to automation by year $t$. The estimated relationships are both expected to be positive, as greater exposure to each factor is likely to be associated with higher probabilities that any given worker is in nontraditional employment. These results are also estimated in subsamples defined by age and gender, to examine heterogeneity in the relationship between nontraditional work and globalization and automation - and, in particular, the extent to which older workers (ages 50-62) are in nontraditional jobs.

The second model focuses on whether these same factors push workers from traditional to nontraditional jobs. It is identical in structure, but the sample is limited to the workers "at risk" of becoming nontraditionally employed: those in traditional jobs at the time of the tax topical module in year $t-1$. Limiting the sample to these workers changes the interpretation of the key estimates slightly: a positive marginal effect indicates that greater exposure to trade or automation in a worker's state of residence is associated with a greater probability that a worker in a traditional job moves to a nontraditional job by year $t$.

The models include state $\left(\zeta_{s}\right)$ and year $\left(\tau_{t}\right)$ fixed effects, as well as a vector of personal and job characteristics, $X_{i s t}$. These variables include indicators for gender, race and Hispanic ethnicity, and marital status; categories for age and educational attainment; the log of family income excluding own earnings, to account for how other available resources may affect job status; indicators for the industry of the respondent's primary job; and whether the current employer employed 25 or fewer employees. The state fixed effects control for invariant state characteristics; in particular, these include the baseline level of different industries. These

\footnotetext{
${ }^{10}$ Due to the probit model's nonlinearity, the results present the marginal effect - that is, the derivative of NonTrad $_{\text {ist }}$ with respect to each variable, averaged across each individual in the sample. Standard errors are calculated for these marginal effects using the Delta method.
} 
controls therefore ensure that the variation identifying the effect of automation and trade is not due to a different starting point of manufacturing, for example. ${ }^{11}$

Table 1 shows the characteristics of workers in nontraditional and traditional jobs (using the more-restrictive definition), as well as those who transition from traditional to nontraditional work from one year to the next. ${ }^{12}$ Although the age distribution of those in traditional and nontraditional work is fairly similar - in contrast to other studies that have found a greater share of older workers in alternative work arrangements - workers in nontraditional jobs are more likely to be male, Hispanic, and unmarried, and are less likely to have a high school or college degree. They have fewer resources available outside of their own work: on average, their total household income excluding their own earnings is only $\$ 9,552$, compared to $\$ 25,582$ for traditionally employed workers. The majority of workers in nontraditional jobs are employed by small firms (which may include independent contracting, but this status is indistinguishable in the SIPP from other self-employment arrangements). The shares of nontraditional jobs in construction, agriculture, retail trade, and services are much higher, while the shares in manufacturing and public administration are noticeably smaller.

Compared to workers in nontraditional jobs overall, those who move from traditional to nontraditional work are even more likely to be male, but less likely to be Hispanic, and their educational attainment looks more like workers in traditional jobs. But workers who move from traditional to nontraditional work have even less income available outside from their own work $(\$ 6,186)$, which may suggest that nontraditional work is used when other options are unavailable.

\footnotetext{
${ }^{11}$ Controlling for time-variant manufacturing shares is inappropriate, as a decline in manufacturing employment, for example, is a predictable consequence of automation, as robots replace workers (see Acemoglu and Restrepo 2019). In fact, over the past few decades, U.S. manufacturing output has steadily increased, even as manufacturing employment has gradually declined (Federal Reserve Bank of St. Louis 2019).

12 The analysis uses information from several waves to determine nontraditional or traditional work status, and part of the analysis focuses on movements from traditional to nontraditional work status. Therefore, the sample is restricted to respondents who are present in all of the waves between the tax topical module wave and the pension topical module wave (inclusive). The sample also excludes individuals who are working but whose jobs are not classified as either traditional or nontraditional because of missing information on pension coverage, health insurance status, or any of the volatility measures. The sample is further restricted to ages 26-62; individuals younger than 26 may still be changing jobs frequently, and some of them will have health insurance coverage through a parent rather than their own employer or a spouse, and individuals 63 or older are likely to be retired.
} 


\section{Results}

Figure 1 shows that the share of workers in nontraditional jobs at ages 26-62 has trended slightly upward, especially under the more-restrictive definition. By 2012, about 19.2 percent of workers were at jobs that did not provide benefits, and 7.6 percent were in jobs that did not provide benefits and were unstable. The figure also shows that the pattern is similar for older workers, although with a smaller increase. By 2012, the share of workers ages 50-62 in jobs without benefits was 17.1 percent, and 7.0 percent had jobs without benefits and with some measure of instability.

The pattern is similar for transitions between traditional and nontraditional work (Figure 2). The transition rate is generally much smaller - between 0.8 and 1.3 percent - because the vast majority of individuals do not change jobs from one year to the next (using the morerestrictive definition). ${ }^{13}$ But the figure exhibits the same pattern as Figure 1: the transition rate increased slightly from 1997-1998 to 2002-2003, fell back in 2005-2006 when the economy was stronger, and then rose sharply during the 2011-2012 period, which coincided with the late stages of the Great Recession's labor market weakness. A similar pattern again emerges when the sample is restricted to workers ages 50-62.

While the nontraditional share and the rate of transitions from traditional to nontraditional jobs are likely attributable in part to the business cycle, the focal empirical question is whether increased import competition and automation are associated with greater prevalence of nontraditional work.

The marginal effects from the probit regressions indicate that greater exposure to automation has a positive and marginally statistically significant relationship with the probability of working in a nontraditional job. Table 2 reports results using both definitions of nontraditional work. The results in column 1 report the less-restrictive definition, where workers are in nontraditional employment if they lack both retirement and health benefits, irrespective of their volatility. Our preferred specification is in column 2, the more-restrictive definition: workers are marked as having nontraditional jobs if the jobs lack both retirement and health benefits and have volatile employment, hours, or earnings. The magnitudes of the estimates for

\footnotetext{
${ }^{13}$ The pattern of transition rates is similar using the benefits-only definition. The low rate of transition from traditional jobs likely reflects the job-lock induced by reliance on an employer for health insurance, particularly among older workers (see, for example, Gruber and Madrian 1995; Garthwaite, Gross, and Notowidigdo 2014; and Wettstein forthcoming).
} 
the automation index are similar in the two specifications, and as expected the more precise definition in column 2 has a much smaller standard error. As a result, with the more-restrictive definition, the estimate on automation and nontraditional work is statistically significant at the 10 -percent level. Because the automation index is measured in standard deviations, the magnitude of the estimate indicates that a one-standard-deviation increase in automation is associated with a 0.7 -percentage-point increase in the probability of being nontraditional, or an 11-percent increase over the mean of 5.8 percent in nontraditional work (for this definition and over the full time period). ${ }^{14}$

Trade, on the other hand, has a statistically insignificant relationship with the probability of working in a nontraditional job under the more-restrictive definition and is in an unexpected direction. And the estimate is actually statistically significant (at the 90-percent level) in that unexpected direction in the regression with the less-restrictive definition of nontraditional employment. These results, therefore, indicate no evidence that nontraditional work is greater in areas more exposed to import competition - if anything, the relationship goes the other way. ${ }^{15}$

Table 3 shows marginal effects estimates for the automation and trade indices for subsamples by gender and age. ${ }^{16}$ Compared to the full sample, estimates for automation are larger for older workers (ages 50-62), and are still marginally statistically significant despite the smaller sample size; a 1-standard deviation increase in automation is associated with a 1percentage-point increase in nontraditional work, or about 17 percent of the mean nontraditional share of 6.0 percent (for this group over the full period). The estimate is statistically insignificant for prime-age workers (ages 35-49), but is largest for younger workers (ages 2634), who may lack the human capital to be able to bargain for a more secure work arrangement when firms are also automating workers' tasks. For both men and women, the estimate on

\footnotetext{
${ }^{14}$ The magnitude of estimates is similar in linear probability models (LPM), though the null is not rejected due to wider confidence intervals. But, due to the low share of nontraditional jobs, about one-quarter of workers end up with predicted values of the nontraditional indicator that are less than zero (or greater than 1) in the LPM model. As a result, this study presents the results only from probit specifications, though LPM results are available upon request.

${ }^{15}$ Other estimates are in line with predictions about nontraditional work. Older individuals, men, non-whites, unmarried individuals, and high school graduates have higher rates of nontraditional work. As income from other family members increases, nontraditional work also falls. Nontraditional work is also more common in small firms and in the construction and agriculture industries, and less common in public administration, mining, manufacturing, and wholesale trade.

${ }^{16}$ These results use the specification reported in column 2 of Table 2, based on the more-restrictive definition of nontraditional work.
} 
automation is positive, but with the smaller sample, the estimates are not statistically significant. The estimate is larger for men - as expected, because men face greater pressure from industrial use of robots (Autor, Dorn, and Hanson forthcoming) - but not significantly so. Also, no subgroup is evidently more likely to be in nontraditional jobs when import competition is high; most estimates are negative, and all but the male sample is statistically insignificant (and that one is in the wrong direction).

The dynamic analysis in Table 4 provides suggestive evidence that more workers transition from traditional to nontraditional work when automation or trade is high, but the only result that is statistically significant is for the less-restrictive definition of nontraditional work (column 1). Neither estimate is statistically significant with the more-restrictive definition, and the magnitudes are quite small (column 2). The small number of workers who move from a traditional job to nontraditional employment likely makes this specification underpowered. ${ }^{17}$

\section{Conclusion}

The apparent rise of alternative work arrangements and labor market weaknesses - slow wage growth, declining health benefit offers, and stagnation in median income and employersponsored retirement coverage - have raised concerns about the precariousness of workers' employment arrangements, especially as globalization and automation continue to put pressure on worker bargaining power and stability. This study examines whether nontraditional employment - jobs characterized by lacking health and retirement benefits and having volatile employment, hours, or earnings - are more common in areas that have seen greater exposure to automation and import competition. It also explores the extent to which these pressures affect older workers specifically.

The results indicate that automation is associated with a greater share of workers in nontraditional employment arrangements; a 1-standard-deviation increase in industrial robot usage is associated with an 11-percent increase in nontraditional work status. This relationship is stronger among older workers, which is concerning given the growing need for older workers to extend their careers to better secure their retirement. Moreover, this result may understate the

\footnotetext{
17 The estimates for other variables indicate the profile of workers who transition from traditional to nontraditional work is similar to the profile of workers in nontraditional work in general. An exception is that those with highschool degrees are least likely to transition, even compared to those with less than a high school degree, perhaps because high-school graduates already had the highest share of nontraditional work.
} 
true relationship between nontraditional work and automation. First, data restrictions lead the analysis to potentially undercount nontraditional jobs. Second, industrial robot usage is only one relatively easy-to-measure component of the effect of automation on employment, so automation may have grown even more than the data currently indicate.

On the other hand, import competition is not associated with greater use of nontraditional work; if anything, the relationship goes the other way, though these results are often not statistically significant. And movements from traditional to nontraditional work are still rare enough that no precise relationship with automation or import competition can be estimated.

These results suggest that as automation continues to increase, it may reduce worker bargaining power and encourage employers to seek less permanent relationships with workers. Older workers in particular may have trouble extending their careers in traditional employment, and may have to settle for jobs that do not include benefits or that leave them with volatile hours or earnings. Workers faced with nontraditional work, therefore, would have to seek the benefits of traditional employment - easy access to retirement savings and health insurance and income stability - from alternative sources. 


\section{References}

Abraham, Katharine G., John Haltiwanger, Kristin Sandusky, and James R. Spletzer. 2018. "Measuring the Gig Economy: Current Knowledge and Open Issues." Working Paper 24950. Cambridge, MA: National Bureau of Economic Research.

Abraham, Katharine G. and Ashley Amaya. 2018. "Probing for Informal Work Activity." Working Paper 24880. Cambridge, MA: National Bureau of Economic Research.

Acemoglu, Daron and David H. Autor. 2011. "Skill, Tasks, and Technologies: Implications for Employment and Earnings." In Handbook of Labor Economics, Vol. 4, edited by Orley Ashenfelter and David Card, 1043-1171. Amsterdam: Elsevier.

Acemoglu, Daron, David Autor, David Dorn, Gordon H. Hanson, and Brendan Price. 2016. "Import Competition and the Great US Employment Sag of the 2000s." Journal of Labor Economics 34(1): 141-198.

Acemoglu, Daron and Pascual Restrepo. 2017. "Robots and Jobs: Evidence from US Labor Markets." Working Paper 23285. Cambridge, MA: National Bureau of Economic Research.

Acemoglu, Daron and Pascual Restrepo. 2018. "The Race between Man and Machine: Implications of Technology for Growth, Factor Shares, and Employment." American Economic Review 108(6): 1488-1542.

Acemoglu, Daron and Pascual Restrepo. 2019. "Automation and New Tasks: How Technology Displaces and Reinstates Labor.” Working Paper 25684. Cambridge, MA: National Bureau of Economic Research.

Anand, Priyanka. 2017. "Health Insurance Costs and Employee Compensation: Evidence from the National Compensation Survey.” Health Economics 26(12): 1601-1616.

Autor, David H. and David Dorn. 2013. "The Growth of Low-Skill Service Jobs and the Polarization of the US Labor Market.” American Economic Review 103(5): 1553-1597.

Autor, David H., David Dorn, and Gordon H. Hanson. 2013. "The China Syndrome: Local Labor Market Effects of Import Competition in the United States." American Economic Review 103(6): 2121-2168.

Autor, David H., David Dorn, and Gordon H. Hanson. 2019 (forthcoming). "When Work Disappears: Manufacturing Decline and the Falling Marriage-Market Value of Young Men." American Economic Review: Insights.

Autor, David H., David Dorn, Gordon H. Hanson, and Jae Song. 2014. "Trade Adjustment: Worker-Level Evidence.” Quarterly Journal of Economics 129(4): 1799-1860. 
Autor, David H., Lawrence F. Katz, and Melissa S. Kearney. 2006. "The Polarization of the U.S. Labor Market.” American Economic Review Papers and Proceedings 96(2): 189-194.

Autor, David H., Lawrence F. Katz, and Melissa S. Kearney. 2008. "Trends in U.S. Wage Inequality: Revising the Revisionists." Review of Economics and Statistics 90(2): 300323.

Autor, David H. and Anna Salomons. 2018. "Is Automation Labor-Displacing? Productivity Growth, Employment, and the Labor Share." Working Paper 24871. Cambridge, MA: National Bureau of Economic Research.

Baily, Martin N. and Barry P. Bosworth. 2014. "US Manufacturing: Understanding its Past and its Potential Future." The Journal of Economic Perspectives 28(1): 3-26.

Balsvik, Ragnhild, Sissel Jensen, and Kjell G. Salvanes. 2015. "Made in China, Sold in Norway: Local Labor Market Effects of an Import Shock." Journal of Public Economics 127: 137144.

Barker, Kathleen and Kathleen Christensen. 1998. Contingent Work: American Employment Relations in Transition. Ithaca, NY: Cornell University Press.

Bloom, Nicholas, Mirko Draca, and John Van Reenen. 2016. "Trade Induced Technical Change? The Impact of Chinese Imports on Innovation, IT and Productivity." The Review of Economic Studies 83(1): 87-117.

Collins, Brett, Andrew Garin, Emilie Jackson, Dmitri Koustas, and Mark Payne. 2019. "Is Gig Work Replacing Traditional Employment? Evidence from Two Decades of Tax Returns." Working Paper. Washington, DC: Internal Revenue Service.

Farrell, Diana and Fiona Greig. 2016. "Paychecks, Paydays, and the Online Platform Economy: Big Data on Income Volatility." Working Paper. New York, NY: J.P. Morgan Chase and Co. Institute.

Federal Reserve Bank of St. Louis. 2019. "FRED Economic Data: Manufacturing Sector Real Output." Available at: https://fred.stlouisfed.org/series/OUTMS on 04/04/2019

Garthwaite, Craig, Tal Gross, and Matthew J. Notowidigdo. 2014. "Public Health Insurance, Labor Supply, and Employment Lock." Quarterly Journal of Economics 129(2): 653696.

Government Accountability Office (GAO). 2015. Contingent Workforce: Size, Characteristics, Earnings, and Benefits. Report GAO-15-168R. Washington, DC.

Graetz, Georg, and Guy Michaels. 2018. "Robots at Work." Review of Economics and Statistics 100(5): 753-758. 
Gruber, Jonathan and Brigitte C. Madrian. 1995. "Health Insurance Availability and the Retirement Decision.” American Economic Review 85(4): 938-948.

Hausman, Jerry A., Jason Abrevaya, and Fiona M. Scott-Morton. 1998. "Misclassification of the Dependent Variable in a Discrete-Response Setting." Journal of Econometrics 87: 239269.

Hemous, David, and Morten Olsen. 2014. "The Rise of the Machines: Automation, Horizontal Innovation and Income Inequality.” Discussion Paper DP10244. London, UK: Centre for Economic Policy Research.

Jackson, Emilie, Adam Looney, and Shanthi Ramnath. 2017. "The Rise of Alternative Work Arrangements: Evidence and Implications for Tax Filing and Benefit Coverage." Working Paper 114. Washington, DC: U.S. Department of the Treasury, Office of Tax Analysis.

Kalleberg, Arne L., Barbara F. Reskin, and Ken Hudson. 2000. "Bad Jobs in America: Standard and Nonstandard Employment Relations and Job Quality in the United States." American Sociological Review 65(2): 256-278.

Katz, Lawrence F. and Alan B. Krueger. 2016. "The Rise and Nature of Alternative Work Arrangements in the United States, 1995-2015." Working Paper. Princeton, NJ: Princeton University.

Katz, Lawrence F. and Alan B. Krueger. 2019. "Understanding Trends in Alternative Work Arrangements in the United States." Working Paper 25425. Cambridge, MA: National Bureau of Economic Research.

Munnell, Alicia H. and Anqi Chen. 2017. "401(k)/IRA Holdings in 2016: An Update from the SCF." Issue in Brief 17-18. Chestnut Hill, MA: Center for Retirement Research at Boston College.

Osterman, Paul. 2013. "Introduction to the Special Issue on Job Quality: What Does It Mean and How Might We Think About It?" Industrial and Labor Relations Review 66(4): 739-752.

Office of the United States Trade Representative. 2018. U.S.-China Trade Facts. Available at: https://ustr.gov/countries-regions/china-mongolia-taiwan/peoples-republic-china

Pierce, Justin R., and Peter K. Schott. 2016. "The Surprisingly Swift Decline of US Manufacturing Employment.” American Economic Review 106(7): 1632-1662.

Robles, Barbara and Marysol McGee. 2016. "Exploring Online and Offline Informal Work: Findings from the Enterprising and Informal Work Activities Survey." Discussion Paper 2016-029. Washington DC: U.S. Board of Governors of the Federal Reserve System. 
U.S. Census Bureau. 2018. U.S. International Trade Data. Washington, DC. Available at: https://www.census.gov/foreign-trade/statistics/historical/index.html

Wettstein, Gal. 2019 (forthcoming) "Retirement Lock and Prescription Drug Insurance:

Evidence from Medicare Part D.” American Economic Journal: Economic Policy. 
Table 1. Summary Statistics on Workers in Nontraditional and Traditional Jobs

\begin{tabular}{|c|c|c|c|}
\hline & Nontraditional & Traditional & $\begin{array}{l}\text { Traditional -> } \\
\text { Nontraditional }\end{array}$ \\
\hline Import competition index & 0.03 & -0.01 & 0.05 \\
\hline Automation index & -0.04 & 0.02 & -0.03 \\
\hline \multicolumn{4}{|l|}{ Age } \\
\hline $26-34$ & $20.98 \%$ & $20.21 \%$ & $20.82 \%$ \\
\hline $35-49$ & 47.83 & 49.46 & 50.09 \\
\hline $50-62$ & 31.19 & 30.34 & 29.09 \\
\hline Female & 35.54 & 45.95 & 31.55 \\
\hline White non-Hispanic & 63.42 & 75.54 & 70.39 \\
\hline Black non-Hispanic & 10.33 & 10.28 & 9.94 \\
\hline Hispanic & 19.27 & 8.90 & 13.40 \\
\hline Asian non-Hispanic & 4.99 & 3.64 & 4.92 \\
\hline Other race/ethnicity & 1.98 & 1.64 & 1.35 \\
\hline Married & 55.06 & 68.32 & 55.21 \\
\hline Less than high school & 17.18 & 5.45 & 8.05 \\
\hline High school degree only & 28.73 & 23.70 & 20.02 \\
\hline Some college or associates degree & 31.66 & 33.60 & 38.81 \\
\hline Bachelor's degree or more & 22.43 & 37.25 & 33.11 \\
\hline Total family income excl. own earnings (median) & $\$ 9,552$ & $\$ 25,582$ & $\$ 6,186$ \\
\hline 25 or fewer employees & $84.14 \%$ & $34.01 \%$ & $76.33 \%$ \\
\hline \multicolumn{4}{|l|}{ Industry } \\
\hline Agriculture, forestry, and fishing & 5.87 & 0.91 & 1.73 \\
\hline Mining & 0.29 & 0.59 & 0.45 \\
\hline Construction & 16.33 & 4.90 & 13.97 \\
\hline Manufacturing & 5.66 & 17.40 & 7.32 \\
\hline Wholesale trade & 3.62 & 4.35 & 4.58 \\
\hline Retail trade & 13.33 & 9.77 & 13.85 \\
\hline Utilities, transportation, and communication & 7.80 & 8.44 & 8.80 \\
\hline Finance, insurance, and real estate & 6.25 & 7.35 & 9.89 \\
\hline Services & 46.74 & 41.16 & 49.86 \\
\hline Public administration & 1.26 & 8.45 & 2.95 \\
\hline Sample size & 3,761 & 62,803 & 509 \\
\hline
\end{tabular}

Note: Nontraditional and traditional status is determined by the more-restrictive definition that includes volatility. The automation and import competition indices are reported as Z-scores - that is, the number of standard deviations the state is above (positive) or below (negative) the mean.

Source: Authors' calculations from the Survey of Income and Program Participation, 1996-2008 panels. 
Table 2. Marginal Effects from Probit Regressions of Nontraditional Work Status

\begin{tabular}{|c|c|c|}
\hline & $(1)$ & $(2)$ \\
\hline Nontraditional definition & No benefits only & $\begin{array}{l}\text { No benefits and } \\
\text { having volatility }\end{array}$ \\
\hline \multirow[t]{2}{*}{ Import competition } & $-0.0079^{*}$ & -0.0044 \\
\hline & $(0.0045)$ & $(0.0032)$ \\
\hline \multirow[t]{2}{*}{ Automation } & 0.0057 & $0.0066^{*}$ \\
\hline & $(0.0050)$ & $(0.0035)$ \\
\hline \multicolumn{3}{|l|}{ Age (omitted: 35-49) } \\
\hline \multirow[t]{2}{*}{$26-34$} & $0.0170^{\star * *}$ & -0.0002 \\
\hline & $(0.0034)$ & $(0.0025)$ \\
\hline \multirow[t]{2}{*}{$50-62$} & $0.0127^{* * *}$ & $0.0068^{* * *}$ \\
\hline & $(0.0030)$ & $(0.0021)$ \\
\hline \multirow[t]{2}{*}{ Female } & 0.0008 & $-0.0119^{* \star *}$ \\
\hline & $(0.0028)$ & $(0.0020)$ \\
\hline \multirow[t]{2}{*}{ Black non-Hispanic } & $0.0274^{* * *}$ & $0.0085^{* *}$ \\
\hline & $(0.0045)$ & $(0.0033)$ \\
\hline \multirow[t]{2}{*}{ Hispanic } & $0.0836^{* * *}$ & $0.0253^{* * *}$ \\
\hline & $(0.0044)$ & $(0.0033)$ \\
\hline \multirow[t]{2}{*}{ Asian non-Hispanic } & $0.0747^{* * *}$ & $0.0321^{* * *}$ \\
\hline & $(0.0064)$ & $(0.0044)$ \\
\hline \multirow[t]{2}{*}{ Other race/ethnicity } & $0.0289^{* * *}$ & $0.0176^{* * *}$ \\
\hline & $(0.0093)$ & $(0.0065)$ \\
\hline \multirow[t]{2}{*}{ Married } & $-0.0554^{* * *}$ & $-0.0210^{* * *}$ \\
\hline & $(0.0032)$ & $(0.0023)$ \\
\hline \multicolumn{3}{|l|}{ Education (omitted: high school degree only) } \\
\hline \multirow[t]{2}{*}{ Less than high school } & $0.0831^{* * *}$ & $0.0290^{* * *}$ \\
\hline & $(0.0045)$ & $(0.0034)$ \\
\hline \multirow[t]{2}{*}{ Some college or associates degree } & $-0.0416^{* * *}$ & $-0.0105^{* * *}$ \\
\hline & $(0.0033)$ & $(0.0024)$ \\
\hline \multirow[t]{2}{*}{ Bachelor's degree or more } & $-0.0912^{* * *}$ & $-0.0246^{* * *}$ \\
\hline & $(0.0036)$ & $(0.0026)$ \\
\hline \multirow[t]{2}{*}{ Log of total family income excl. own earnings } & $-0.0032^{* * *}$ & $-0.0020^{* * *}$ \\
\hline & $(0.0004)$ & $(0.0003)$ \\
\hline \multirow[t]{2}{*}{25 or fewer employees } & $0.1813^{* * *}$ & $0.0938^{* * *}$ \\
\hline & $(0.0025)$ & $(0.0022)$ \\
\hline Sample size & 74,308 & 66,214 \\
\hline Pseudo- $\mathrm{R}^{2}$ & 0.243 & 0.218 \\
\hline
\end{tabular}

Note: Regressions also include state and year fixed effects and industry dummies. ${ }^{*} \mathrm{p}<0.10,{ }^{* *} \mathrm{p}<0.05,{ }^{* * *} \mathrm{p}<0.01$. Source: Authors' estimates from the Survey of Income and Program Participation, 1996-2008 panels. 
Table 3. Marginal Effects from Probit Regressions of Nontraditional Work Status, by Age and Gender

\begin{tabular}{cccc}
\hline & $\begin{array}{c}\text { Import } \\
\text { competition }\end{array}$ & Automation & $\begin{array}{c}\mathrm{N} \text { and } \\
\text { pseudo- } \mathrm{R}^{2}\end{array}$ \\
\hline Age & & & \\
$50-62$ & -0.0090 & $0.0102^{*}$ & 20,695 \\
& $(0.0059)$ & $(0.0056)$ & 0.208 \\
$35-49$ & -0.0009 & 0.0004 & 32,897 \\
& $(0.0044)$ & $(0.0051)$ & 0.235 \\
$26-34$ & -0.0052 & $0.0216^{* *}$ & 12,509 \\
& $(0.0074)$ & $(0.0086)$ & 0.231 \\
Men & $-0.0105^{* *}$ & 0.0075 & 35,173 \\
& $(0.0046)$ & $(0.0053)$ & 0.238 \\
Women & 0.0045 & 0.0048 & 31,006 \\
& $(0.0043)$ & $(0.0043)$ & 0.187 \\
\hline
\end{tabular}

Note: Regressions use the more-restrictive definition of nontraditional work status. ${ }^{*} \mathrm{p}<0.10,{ }^{* *} \mathrm{p}<0.05$. Source: Authors' estimates from the Survey of Income and Program Participation, 1996-2008 panels. 
Table 4. Marginal Effects from Probit Regressions of Moving from Traditional to Nontraditional Work Status

\begin{tabular}{|c|c|c|}
\hline & (1) & (2) \\
\hline Nontraditional definition & No benefits only & $\begin{array}{l}\text { No benefits and } \\
\text { having volatility }\end{array}$ \\
\hline Import competition & -0.0022 & 0.0013 \\
\hline Automation & $\begin{array}{c}(0.0028) \\
0.0061 *\end{array}$ & $\begin{array}{r}(0.0018) \\
0.0018\end{array}$ \\
\hline \multicolumn{3}{|l|}{ Age (omitted: $35-49$ ) } \\
\hline $26-34$ & $\begin{array}{l}0.0057^{* * *} \\
(0.0020)\end{array}$ & $\begin{array}{r}0.0008 \\
(0.0012)\end{array}$ \\
\hline $50-62$ & $\begin{array}{c}0.0031^{*} \\
(0.0019)\end{array}$ & $\begin{array}{r}0.0009 \\
(0.0011)\end{array}$ \\
\hline Female & $\begin{array}{l}-0.0053^{* * *} \\
(0.0017)\end{array}$ & $\begin{array}{l}-0.0044^{* * *} \\
(0.0011)\end{array}$ \\
\hline Black non-Hispanic & $\begin{array}{r}0.0030 \\
(0.0029)\end{array}$ & $\begin{array}{r}0.0010 \\
(0.0018)\end{array}$ \\
\hline Hispanic & $\begin{array}{l}0.0193^{* * * *} \\
(0.0028)\end{array}$ & $\begin{array}{c}0.0037^{*} \\
(0.0019)\end{array}$ \\
\hline Asian non-Hispanic & $\begin{array}{l}0.0142 * * * \\
(0.0039)\end{array}$ & $\begin{array}{l}0.0046^{* *} \\
(0.0023)\end{array}$ \\
\hline Other race/ethnicity & $\begin{array}{r}-0.0026 \\
(0.0062)\end{array}$ & $\begin{array}{r}-0.0001 \\
(0.0039)\end{array}$ \\
\hline Married & $\begin{array}{l}-0.0141^{* * * *} \\
(0.0020)\end{array}$ & $\begin{array}{l}-0.0038^{* * *} \\
(0.0013)\end{array}$ \\
\hline \multicolumn{3}{|l|}{ Education (omitted: high school degree only) } \\
\hline Less than high school & $\begin{array}{l}0.0146^{* * *} \\
(0.0032)\end{array}$ & $\begin{array}{l}0.0052 * * \\
(0.0021)\end{array}$ \\
\hline Some college or associates degree & $\begin{array}{r}-0.0019 \\
(0.0021)\end{array}$ & $\begin{array}{l}0.0029^{* *} \\
(0.0013)\end{array}$ \\
\hline Bachelor's degree or more & $\begin{array}{l}-0.0122 * * * \\
(0.0023)\end{array}$ & $\begin{array}{r}0.0010 \\
(0.0014)\end{array}$ \\
\hline Log of total family income excl. own earnings & $\begin{array}{r}-0.0003 \\
(0.0003)\end{array}$ & $\begin{array}{l}-0.0004 * * \\
(0.0002)\end{array}$ \\
\hline 25 or fewer employees & $\begin{array}{l}0.0341^{* * * *} \\
(0.0017)\end{array}$ & $\begin{array}{l}0.0154^{* * *} \\
(0.0012)\end{array}$ \\
\hline Sample size & $\begin{array}{r}53,410 \\
0,097\end{array}$ & $\begin{array}{r}51,916 \\
0113\end{array}$ \\
\hline
\end{tabular}

Note: Regressions also include state and year fixed effects and industry dummies. ${ }^{*} \mathrm{p}<0.10,{ }^{* *} \mathrm{p}<0.05,{ }^{* * *} \mathrm{p}<0.01$. Source: Authors' estimates from the Survey of Income and Program Participation, 1996-2008 panels. 
Figure 1. Share of Workers in Nontraditional Employment, by Age and Definition

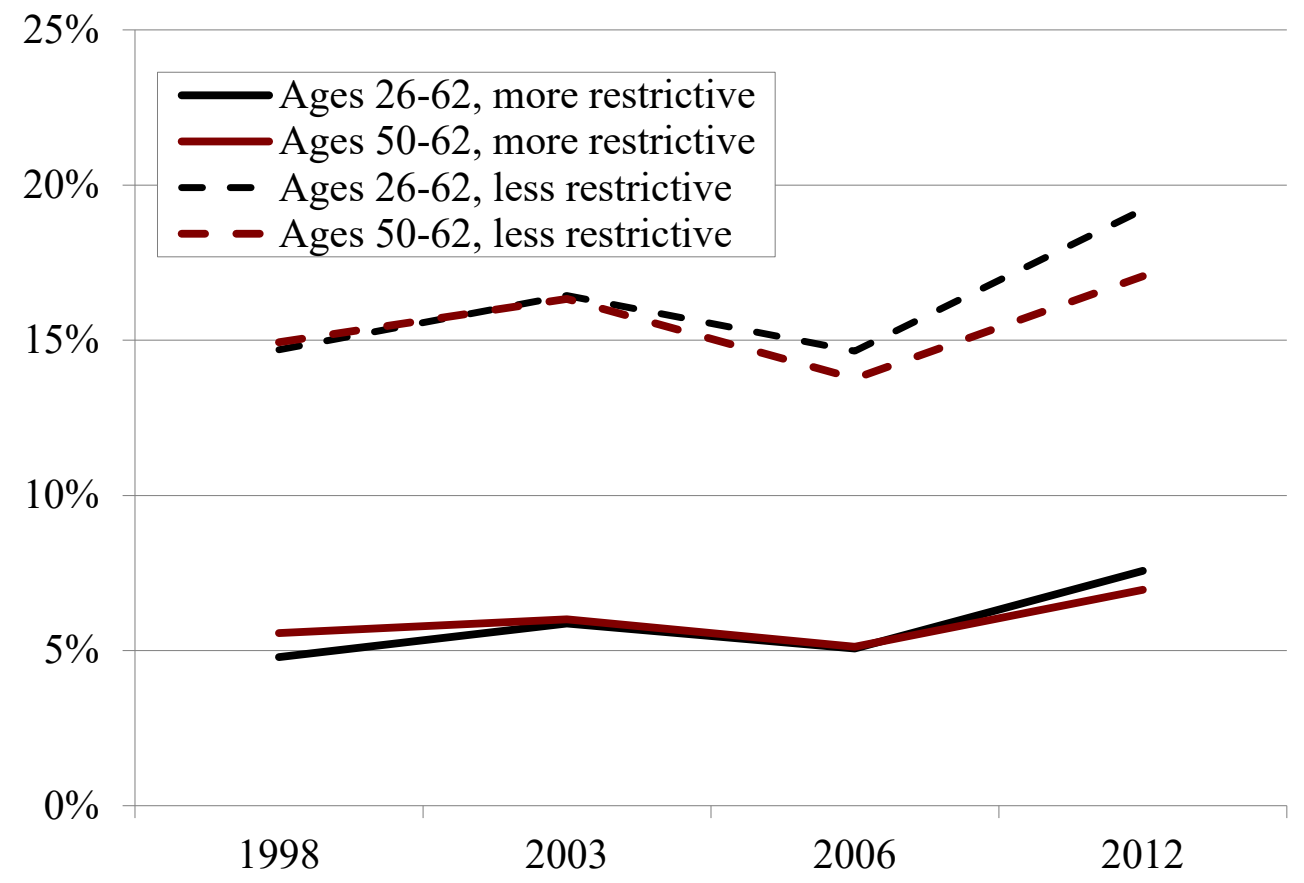

Note: The total number of workers only includes individuals who can be definitively categorized as traditional or nontraditional.

Source: Authors' calculations from the Survey of Income and Program Participation, 1996-2008 panels. 
Figure 2. Share of Workers Moving from Traditional to Nontraditional Employment, by Age

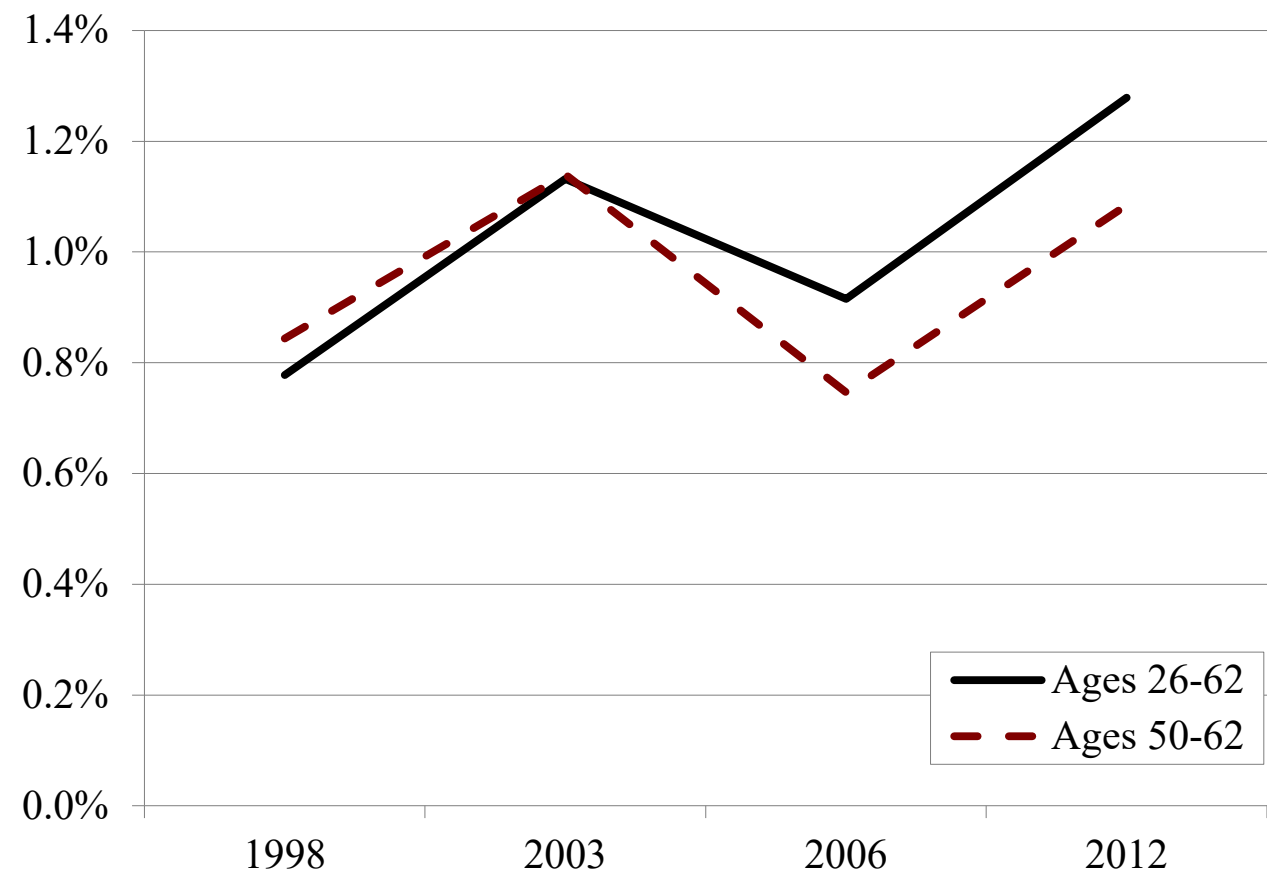

Note: The transition rate uses the more-restrictive definition of nontraditional work status, and the sample is limited to those in traditional jobs one year prior.

Source: Authors' calculations from the Survey of Income and Program Participation, 1996-2008 panels. 


\section{RECENT WORKING PAPERS FROM THE CENTER FOR RETIREMENT RESEARCH AT BOSTON COLLEGE}

Do States Adjust Medicaid Enrollment in Response to Capitation Rates? Evidence from the Medicare Part D Clawback

Laura D. Quinby and Gal Wettstein, June 2019

The Effect of Medicare Part D on Evergreening, Generic Entry, and Drug Prices

Geoffrey T. Sanzenbacher and Gal Wettstein, May 2019

Is the Drop in Fertility Due to The Great Recession or a Permanent Change?

Alicia H. Munnell, Anqi Chen, and Geoffrey T. Sanzenbacher, March 2019

Will Fewer Children Boost Demand for Formal Caregiving?

Gal Wettstein and Alice Zulkarnain, March 2019

The Relationship Between Occupational Requirements and SSDI Activity

Matthew S. Rutledge, Alice Zulkarnain, and Sara Ellen King, February 2019

How Does Contingent Work Affect SSDI Benefits?

Matthew S. Rutledge, Alice Zulkarnain, and Sara Ellen King, February 2019

Do Pension Cuts for Current Employees Increase Separation?

Laura D. Quinby and Gal Wettstein, January 2019

Competition, Asymmetric Information, and the Annuity Puzzle: Evidence from a Government-Run Exchange in Chile

Gastón Illanes and Manisha Padi, January 2019

Failure to Contribute: An Estimate of the Consequences of Non- and Underpayment of Self-Employment Taxes by Independent Contractors and On-Demand Workers on Social Security

Caroline Bruckner and Thomas L. Hungerford, January 2019

How Much Income Do Retirees Actually Have? Evaluating the Evidence from Five National Datasets

Anqi Chen, Alicia H. Munnell, and Geoffrey T. Sanzenbacher, November 2018

The Minimum Wage and Incentives for Full-Time Work Under the Social Security Retirement Earnings Test

Gary V. Engelhardt, October 2018

All working papers are available on the Center for Retirement Research website (https://crr.bc.edu) and can be requested by e-mail (crr@bc.edu) or phone (617-552-1762). 